\title{
The impact of Information Technology (IT) use on children's cognitive, social, psychological and moral development
}

\author{
L. A. Jackson, Y. Zhao, H. E. Fitzgerald, A. von Eye \& R. Harold \\ Michigan State University, USA
}

\begin{abstract}
The Children and Technology Project, funded by the National Science Foundation, is designed to address the broad question "How does children's use of Information Technology (IT) influence their cognitive, social, psychological and moral development?" Based on an ecological systems theory perspective, IT use is conceptualized as a reciprocal proximal process that occurs over time and is embedded in a social and cultural context. Thus, to understand the impact of IT use on children's developmental outcomes requires a consideration of Child and Contextual factors as they interact with IT use over Time.

A longitudinal study is underway that consists of six waves of data collection from middle-school children, their parents and teachers to assess Person and Contextual factors, IT use, and a diverse set of cognitive, social, psychological and moral developmental outcomes. In addition to examining the overall impact of IT use on development, the study will examine whether impact is different for children living in disadvantaged environments than for other children, as suggested by ecological system theory. Findings from the project will have implications for how IT is used in educational settings, parental regulation of children's IT use, and policy-makers decisions about resource allocation for IT in educational and other public settings.

Keywords: child development, technology use, cognitive, social, psychological, moral development.
\end{abstract}

\section{Introduction}

Guided by an ecological systems theory perspective on human development, the Children and Technology Project is designed to examine the impact of 
information technology (IT) use on children's cognitive, social, psychological and moral development. Of particular interest is determining whether IT use buffers against the adverse effects of disadvantaged environments on child development. Based on Bronfenbrenner's ecological systems theory [1], IT use is conceptualized as a reciprocal proximal process that occurs over time and is embedded in a social and cultural context. Thus, to understand the impact of IT use requires understanding Person (Child) and Contextual factors as they interact with IT use over Time.

\section{An ecological systems theory view of human development}

Bronfenbrenner's ecological systems theory is one of the earliest developmental systems perspectives in psychology [1]. Like other systems perspectives [2], Bronfenbrenner's theory views human development as a dynamic synthesis of multiple and integrated levels of organization that occurs over time [3-7]. The theory encompasses four components in reciprocal dynamic interaction with each other: Proximal processes, Person, Context and Time. These components, described next, influence the broad developmental outcomes of competence and dysfunction. Competence is defined as the ability to direct and control one's behavior, cope effectively under stress, acquire knowledge and skills, establish and maintain mutually rewarding relationships and modify and construct one's physical, social and symbolic environment. Dysfunction is defined as a recurrent manifestation of difficulties in maintaining control and integrating behavior across situations.

Proximal processes are complex, reciprocal interactions between an active, evolving Person and other persons, objects and symbols in the immediate environment. They are viewed as "the primary engines of development" [1]. For Proximal processes to be effective (i.e., influence development) they must involve specific activities that occur on a fairly regular basis over an extended period of time. Parent-child interactions, group play, reading, learning new skills and performing complex tasks are all examples of Proximal processes.

From a developmental systems perspective, Proximal processes are themselves the result of distal influences that cumulate over time. Thus, Proximal processes are influenced by distal events and become dimensions of Context in which subsequent Proximal processes occur. For example, the parent-child relationship, a Proximal process that has cumulating effects on development, becomes a dimension of Context for IT activities, which are themselves Proximal processes whose effects cumulate over time and become a dimension of Context for other Proximal processes, and so on.

The Person in ecological systems theory consists of forces, resources and demand characteristics which can facilitate or impede Proximal processes (i.e., be developmentally generative or disruptive). Forces include: a) behavioral dispositions that set Proximal processes in motion and sustain them (e.g., curiosity, initiating activity); b) selective responsiveness which refers to a differentiated response to, attraction by, and exploration of aspects of the physical and social world; c) structuring proclivities which refer to the tendency 
to engage and persist in progressively more complex activities; and d) directive belief systems which are beliefs about the self as an active agent in relation to the environment (e.g., locus of control, self-esteem; aggressiveness, impulse control). Depending on these forces a Person will be more or less disposed to engage in Proximal processes that require progressively more complex patterns of reciprocal interactions over extended periods of time.

Resources refer to characteristics of the Person that in themselves provide no selective disposition to action, but constitute assets and liabilities that influence the capacity for Proximal processes. Characteristics that limit or disrupt the functional integrity of the Person (e.g., genetic defects, illness, brain damage) and characteristics that facilitate successful engagement in Proximal processes (e.g., abilities, experience) are examples of resources.

Demand characteristics refer to the Person's capacity to invite or discourage reactions from the social environment that can facilitate or disrupt Proximal processes. Examples of demand characteristics are physical attractiveness and "personality," in terms of their social stimulus value.

Time is the third component of ecological systems theory. Time is a critical component for understanding intra-individual consistency, variability and change across multiple events and multiple occasions of the same event.

Microtime refers to the continuity versus discontinuity within ongoing episodes of Proximal processes. Mesotime refers to the periodicity of these episodes across broader time intervals, such as days or weeks. Macrotime refers to the changing expectations and events in the larger society, both within and across generations, as they influence and are influenced by processes and outcomes of human development over the life span and across generations. Developmental processes and outcomes produce large-scale changes over time in the state and structure of the broader society. Chronosystem refers to the patterning of environmental events and transitions across the lifespan, as well as the socio-historical circumstances and conditions.

Context (environment) is the fourth component of ecological systems theory. Context is viewed as either facilitating or inhibiting Proximal processes. Sociodemographic characteristics, culture, family and peer relationships are all elements of Context that interact with Person and Proximal processes over Time to sculpt individual development. Other elements of Context are political conditions, social policy, and societal attitudes (e.g., racism). Contexts influences Proximal processes and therefore developmental outcomes "not only in terms of the resources they make available, but also in terms of the degree to which they provide the stability and consistency over time that proximal processes require for their effective functioning" [1].

Early discussions of Bronfenbrenner's ecological systems theory viewed Context as "a set of nested structures, each inside the other like a set of Russian dolls" [8, p. 3]. The microsystem is the first level of Context and consists of the setting in which the Person lives. It includes family, friends, classmates, peers, neighbors, church, youth groups and athletic teams. The Person is an active participant in constructing the microsystem. The mesosystem ${ }_{2}$ or second level, includes interactions and relationships among microsystems. For example, 
relations between family experiences and school experiences, and between school experiences and peer experiences are parts of the mesosystem. The exosystem refers to social settings in which the Person does not have an active role, but which nevertheless influence her or his experiences in the immediate context. Included in the exosystem are welfare services, mass media, parent's friends, family friends, school board, church and national organizations. For example, a parent's job experiences may affect her behavior at home, thus affecting her child's development. Finally, the macrosystem includes attitudes and values of the culture in which the individual lives, including local, regional, national and international culture (e.g., ethnic heritage, national heritage, economic structure, political system, religious tradition). For example, attitudes about race/ethnicity and moral, religious, and ethical values are part of the macrosystem, as are national and global values regarding information technology (IT) and the global economy.

\section{Ecological systems theory and the effects of IT use on children's development}

Three basic propositions of ecological systems theory provide a framework for understanding the effects of IT use on children's development. First, the theory proposes that Person characteristics interact with Proximal processes and Context over Time to influence development. Thus, to predict the effects of IT use, conceptualized as a Proximal process, requires a consideration of: (1) quantitative and qualitative dimensions of IT use (i.e., frequency and nature of IT use); (2) child characteristics (Person) that may be related to IT use; (3) Contextual factors surrounding IT use; 4) IT use over time.

Second, the theory proposes that in disadvantaged environments, manifestations of developmental dysfunction are more frequent and severe than in enriched environments. Consequently, in disadvantaged environments Proximal processes are more likely to be aimed at reducing dysfunction than at augmenting competence. The reverse is true in enriched environments; Proximal processes are more likely to be aimed at augmenting competence than at reducing dysfunction. For example, inadequate child care is more likely to have an aggregating negative impact on children living in disadvantaged environments than on children living in enriched environments. Thus, the theory predicts that in disadvantaged environments, the effects of IT use on (reducing) dysfunctional outcomes will be stronger than its effects on (augmenting) competence outcomes. The reverse will be true in enriched environments; IT use will have stronger effects on (augmenting) competence than on (reducing) dysfunction.

Third, ecological systems theory proposes that interventions designed to enhance Proximal processes will be more effective in disadvantaged environments than in enriched environments. The rational for this proposition is that interventions in disadvantaged environments are more likely to engage Proximal processes that would otherwise not be engaged. Thus, the theory predicts that IT use will have stronger effects on developmental outcomes in disadvantaged than enriched environments (although weaker effects on 
(augmenting) competence than on (decreasing) dysfunction; see preceding prediction).

In the March 2004 issue of the American Psychologist, Gary Evan's abstract to his article titled "The environment of childhood poverty" captures many of the elements of a disadvantaged environment, as described by Bronfenbrenner et al. [1] described almost a decade earlier:

"Poor children confront widespread environmental inequities. Compared with their economically advantaged counterparts they are exposed to more family turmoil, violence, separation from their families, instability, and chaotic households. Poor children experience less social support and their parents are less responsive and more authoritarian. Low-income children are read to relatively infrequently, watch more $\mathrm{TV}$, and have less access to books and computers. Low-income parents are less involved in children's school activities. The air and the water poor children consume are more polluted. Their homes are more crowded, noisier and of lower quality. Low-income neighborhoods are more dangerous, offer poorer municipal services, and suffer greater physical deterioration. Predominantly low-income schools and day care are inferior. The accumulation of multiple environmental risks rather than singular risk exposure may be an especially pathogenic aspect of childhood poverty."

\section{The Children and Technology Project}

The Children and Technology Project is a three-year longitudinal study of children's IT use and its impact on developmental outcomes in the cognitive, social, psychological and moral domains. The conceptual model guiding this research is based on ecological systems theory and presented in Figure 1. As indicated in the model, initially (Time 1) Person (Child) factors (e.g., temperament, self-concept) and Contextual factors (e.g., socio-demographic characteristics, parent-child relationship) independently and interactively (arrow between the two) influence IT use (nature and frequency), which in turn influences cognitive, social, psychological and moral outcomes. These outcomes in turn influence the Person at Time 2, who, in interaction with Contextual factors present at Time 2, engages (or not) in IT use, which again influences cognitive, social, psychological and moral outcomes, and so on through Time.

Two characteristics of the conceptual model in Figure 1 are worthy of note. First, Person and Contextual factors change over time. Second, some (but not all) Person and Contextual factors are expected to be influenced by IT use (i.e., Outcomes of IT use), and to subsequently influence Person and Contextual factors at the next point in time. For example, visual skills is a Person characteristic at Time 1 expected to influence IT use, and to be influenced by IT use (i.e., an Outcome), resulting in a new level of visual skills in the Person at Time 2. Parental relationships at Time 1 is a Contextual factor that may influence IT use and be influenced by use, resulting in a new level of this Contextual factor at Time 2. On the other hand, family income, a Contextual characteristic at Time 1 that may influence IT use is not expected to be influenced by IT use. 


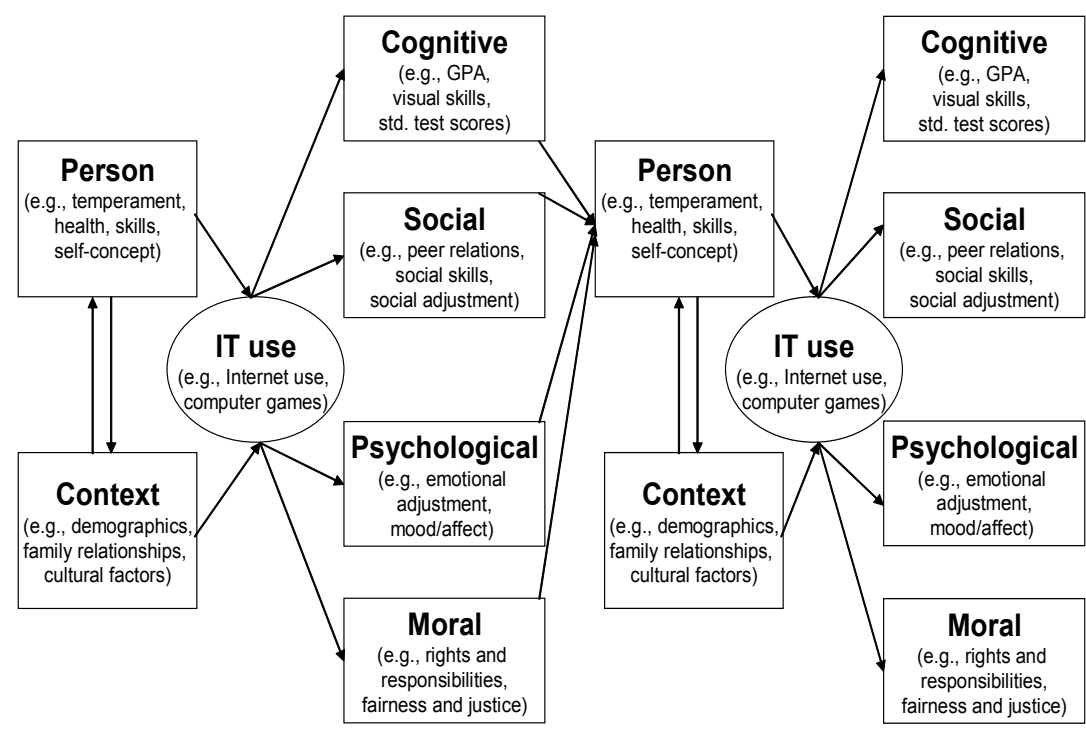

Time

Figure 1: How IT use impacts children's development.

The basic hypotheses for the proposed research are as follows:

Hypothesis 1: The effects of IT use on developmental outcomes (i.e., competence and dysfunction) in the cognitive, social, psychological and moral domains will depend on Person (Child) and Contextual factors and on quantitative and qualitative aspects of IT use (i.e., Proximal processes) over Time.

Hypothesis 2: In disadvantaged environments the effects of IT use on dysfunctional outcomes will be stronger than its effects on competence outcomes. The reverse will be true in enriched environments (i.e., IT use will have stronger effects on competence than dysfunctional outcomes).

Hypothesis 3: IT use will have stronger effects on developmental outcomes in disadvantaged environments than in enriched environments.

For example, to address the broad question "Does IT use influence cognitive development?" the child's level of cognitive development at Time 1 other Child characteristics (e.g., social self-concept) and characteristics of the Context (e.g., socio-demographic factors) will be used to predict the nature and extent of IT use. IT use at Time 1 will be used to predict cognitive outcomes, controlling for level of cognitive development at Time 1. Cognitive outcomes then serve as cognitive characteristics of the Person (Child) at Time 2 for the prediction of IT 
use, which in turn is used to predict later cognitive outcomes, and so on. Thus, Outcomes at one time period have the potential to influence Person and Contextual factors in a subsequent time period. Context effects on Outcomes are mediated by their effects on Person factors and IT use. Moreover, Context effects, which include both structural and relational effects, cumulate over time.

A variety of factors will be used to categorize the Context (environment) as disadvantaged or not (e.g., parent income and education, parent-child relationship). This will permit examination of whether using different factors for categorization results in different effects of IT use on developmental outcomes. For example, are the developmental effects of IT use different when sociodemographic characteristics are used to categorize the Context as disadvantaged than when dysfunctional family relationships are the basis for this categorization?

Participants in the project are $6007^{\text {th }}$ graders recruited from middle schools geographically distributed throughout the lower peninsula of Michigan, U.S. The goal is for half of these participants to be female and half to be members of underserved racial/ethnic groups in the U.S. (i.e., African Americans, Native Americans, Hispanic Americans). Multiple measures of cognitive, social, psychological and moral outcomes will be obtained from children, parents and teachers. All participants are compensated for completing surveys and other measures of cognitive, social, psychological and moral development, summarized in Table 1.

Table 1: $\quad$ Measures in the Children and Technology Project.

\begin{tabular}{|l|l|l|lr|}
\hline \multicolumn{1}{|c|}{ Measure } & $\begin{array}{l}\text { Target/ } \\
\text { Source }\end{array}$ & Focus* & \multicolumn{1}{|c|}{ Brief description } \\
\hline $\begin{array}{l}\text { Child Health and } \\
\text { Development }\end{array}$ & $\begin{array}{l}\text { Child/ } \\
\text { Parent }\end{array}$ & Person & $\begin{array}{l}\text { Physical growth and } \\
\text { development, health/disability }\end{array}$ \\
\hline $\begin{array}{l}\text { Temperament: } \\
\text { Dimensions of } \\
\text { Temperament Scale }\end{array}$ & $\begin{array}{l}\text { Child/ } \\
\text { Parent }\end{array}$ & Person & $\begin{array}{l}\text { 54-items, 11 factors (e.g., } \\
\text { Activity Level, Approach- } \\
\text { withdrawal, Flexibility) }\end{array}$ \\
\hline $\begin{array}{l}\text { Child Adjustment: } \\
\text { Child Behavior } \\
\text { Checklist }\end{array}$ & $\begin{array}{l}\text { Child/ } \\
\text { Parent } \\
\text { Teacher } \\
\text { Child }\end{array}$ & $\begin{array}{l}\text { Person, } \\
\text { Outcome } \\
\text { (C, S,P) }\end{array}$ & $\begin{array}{l}\text { Academic, social fund } \\
\text { emotional functioning (e.g., } \\
\text { externalizing, internalizing } \\
\text { behavior) }\end{array}$ \\
\hline $\begin{array}{l}\text { Self-Concept } \\
\text { Esteem }\end{array}$ & $\begin{array}{l}\text { Child/ } \\
\text { Child }\end{array}$ & $\begin{array}{l}\text { Person, } \\
\text { Outcome } \\
\text { (C, S, P) }\end{array}$ & $\begin{array}{l}\text { Abilities and stature vis-à-vis } \\
\text { other children; 6 domains (e.g., } \\
\text { school, peer) }\end{array}$ \\
\hline $\begin{array}{l}\text { Academic } \\
\text { Performance } \\
\text { (MEAP; GPA) }\end{array}$ & $\begin{array}{l}\text { Child/ } \\
\text { Child }\end{array}$ & $\begin{array}{l}\text { Person, } \\
\text { Outcome } \\
\text { (C) }\end{array}$ & $\begin{array}{l}\text { Reading, Math, Overall } \\
\text { Academic Performance }\end{array}$ \\
\hline $\begin{array}{l}\text { Academic } \\
\text { Performance } \\
\text { WRAT }\end{array}$ & $\begin{array}{l}\text { Child/ } \\
\text { Child }\end{array}$ & $\begin{array}{l}\text { Person, } \\
\text { Outcome } \\
\text { (C) }\end{array}$ & $\begin{array}{l}\text { Reading, spelling, and } \\
\text { mathematics }\end{array}$ \\
\hline
\end{tabular}


Table 1: $\quad$ Continued.

\begin{tabular}{|c|c|c|c|}
\hline Visual Ability & $\begin{array}{l}\text { Child/ } \\
\text { Child }\end{array}$ & $\begin{array}{l}\text { Person, } \\
\text { Outcome } \\
\text { (C) }\end{array}$ & Widely used standardized test \\
\hline $\begin{array}{l}\text { Peer Relationships } \\
\text { Profile }\end{array}$ & $\begin{array}{l}\text { Child/ } \\
\text { Child }\end{array}$ & $\begin{array}{l}\text { Person, } \\
\text { Outcome } \\
\text { (S) }\end{array}$ & 54-items; 3 dimensions \\
\hline $\begin{array}{l}\text { Sibling } \\
\text { Relationship } \\
\text { Profile }\end{array}$ & $\begin{array}{l}\text { Child/ } \\
\text { Child }\end{array}$ & $\begin{array}{l}\text { Person, } \\
\text { Outcome } \\
\text { (S) }\end{array}$ & 51-items, 4 dimensions \\
\hline $\begin{array}{l}\text { Moral } \\
\text { Development }\end{array}$ & $\begin{array}{l}\text { Child/ } \\
\text { Child }\end{array}$ & $\begin{array}{l}\text { Person, } \\
\text { Outcome } \\
\text { (M) }\end{array}$ & $\begin{array}{l}\text { Response to moral/ethnical } \\
\text { questions; Josephson Institute } \\
\text { Survey }\end{array}$ \\
\hline $\begin{array}{l}\text { Cognitive, social } \\
\text { and psychological } \\
\text { outcomes }\end{array}$ & $\begin{array}{l}\text { Child/ } \\
\text { Child }\end{array}$ & $\begin{array}{l}\text { Outcome } \\
(\mathrm{C}, \mathrm{S}, \mathrm{Ps})\end{array}$ & $\begin{array}{l}\text { Self-reported school } \\
\text { performance, social behavior, } \\
\text { affect, activities }\end{array}$ \\
\hline $\begin{array}{l}\text { Socio- } \\
\text { Demographic } \\
\text { Information }\end{array}$ & $\begin{array}{l}\text { Context } \\
\text { Parent }\end{array}$ & Context & $\begin{array}{l}\text { Family/household gender, age, } \\
\text { race/ethnicity, religion, income }\end{array}$ \\
\hline $\begin{array}{l}\text { Parent Perception: } \\
\text { Parent Form } \\
\text { Child Form }\end{array}$ & $\begin{array}{l}\text { Parent/ } \\
\text { Parent } \\
\text { Parent/ } \\
\text { Child }\end{array}$ & Context & $\begin{array}{l}\text { 18-items on parenting styles; } \\
\text { half positive and half negative }\end{array}$ \\
\hline $\begin{array}{l}\text { Parent Monitoring: } \\
\text { Parent Form } \\
\text { Child Form }\end{array}$ & $\begin{array}{l}\text { Parent/ } \\
\text { Parent/ } \\
\text { Child }\end{array}$ & Context & $\begin{array}{l}\text { 23-items on supervision and } \\
\text { monitoring }\end{array}$ \\
\hline $\begin{array}{l}\text { Children's Social } \\
\text { Support } \\
\text { Questionnaire } \\
\end{array}$ & $\begin{array}{l}\text { Context } \\
\text { /Child }\end{array}$ & Context & $\begin{array}{l}16 \text { items; } 4 \text { areas of support } \\
\text { (e.g., advice/information) }\end{array}$ \\
\hline $\begin{array}{l}\text { Family } \\
\text { Environment: }\end{array}$ & $\begin{array}{l}\text { Context } \\
\text { Parent/ } \\
\text { /Child }\end{array}$ & Context & $\begin{array}{l}4 \text { scales; cohesion, conflict, } \\
\text { moral-religious emphasis, and } \\
\text { achievement orientation }\end{array}$ \\
\hline $\begin{array}{l}\text { Work Satisfaction } \\
\text { Questionnaire }\end{array}$ & $\begin{array}{l}\text { Parent/ } \\
\text { Parent }\end{array}$ & Context & $\begin{array}{l}\text { 78/ attitudes toward work, job } \\
\text { (e.g., job satisfaction) }\end{array}$ \\
\hline Family Crisis List & $\begin{array}{l}\text { Family/ } \\
\text { Parent }\end{array}$ & Context & 40 -item list of family troubles \\
\hline $\begin{array}{l}\text { Technology } \\
\text { Context } \\
\text { HomeNetToo }\end{array}$ & $\begin{array}{l}\text { Context } \\
\text { Child }\end{array}$ & Context & $\begin{array}{l}\text { Availability of IT (and types) } \\
\text { in home, school, elsewhere }\end{array}$ \\
\hline $\begin{array}{l}\text { Technology Use } \\
\text { HomeNetToo }\end{array}$ & $\begin{array}{l}\text { Child/ } \\
\text { Child }\end{array}$ & $\begin{array}{l}\text { Proximal } \\
\text { processes }\end{array}$ & $\begin{array}{l}\text { Nature and frequency of IT } \\
\text { use, skills, interest }\end{array}$ \\
\hline $\begin{array}{l}\text { Time Allocation } \\
\text { HomeNetToo }\end{array}$ & $\begin{array}{l}\text { Child/ } \\
\text { Parent }\end{array}$ & Context & $\begin{array}{l}\text { Daily time allocation among } 16 \\
\text { activities }\end{array}$ \\
\hline
\end{tabular}

Note. ${ }^{*} \mathrm{C}=$ Cognitive, $\mathrm{S}=$ Social, $\mathrm{P}=$ Psychological, $\mathrm{M}=$ Moral. 


\section{Summary}

The Children and Technology project is based on a rich theoretical framework for examining the impact of IT use on children's development. Findings will advance knowledge and understanding in the fields of developmental science, IT and education. What passes for knowledge and understanding of the developmental consequences of children's IT use is often little more than media hype and anecdote. Systematic, comprehensive, longitudinal studies that help to establish cause-effect relationships are needed to shed light on whether or not children's use of IT is changing their lives and if so, how.

Findings from the project will have broad societal impacts. They will directly address the consequences for children of using IT. Implications for underserved groups will be especially important to educators and policy makers as IT becomes more ubiquitous in everyday life. Parents will also benefit from information about the potential benefits and liabilities of their children's IT use.

\section{References}

[1] Bronfenbrenner, U. \& Morris, P. The ecology of developmental processes. In W. Damon (Series Ed.), \& R. M. Lerner (Vol. Ed.), Handbook of child psychology: Theoretical models of human development. $\left(5^{\text {th }}\right.$ Ed., Vol. 1, pp. 993-1028). New York: John Wiley \& Sons, Inc., 1998.

[2] Ford, D. H., \& Lerner, R. M. Developmental system theory: An integrative approach. Newbury Park, CA: Sage, 1992.

[3] Bertalanffy, L. General systems theory (Revised Edition). New York: George Braziller, Inc., 1998.

[4] Cairns, R. B. Social development: The origins and plasticity of social interchanges. San Francisco: Freeman, 1979.

[5] Gottlieb, G. Individual differences and evolution: The genesis of novel behavior. New York: Oxford University Press, 1992.

[6] Kuo, Z.Y. The dynamics of human development: An epigenetic view. New York: Plenum Press, 1976.

[7] Schneirla, T. C. The concept of development in comparative psychology. In D. B. Harris (Ed.). The concept of development (pp. 78-108). Minneapolis, MN: University of Minnesota Press, 1957.

[8] Bronfenbrenner, U. The ecology of human development: Experiments by nature and design. Cambridge, MA: Harvard University Press, 1979.

[9] Duncan, G. J., Yeung, W., Brooks-Gunn, J. \& Smith, J. How much does poverty affect the life chances of children? American Sociological Review, 63, pp. 406-423, 1998.

[10] Evans, G. W. The environment of childhood poverty. American Psychologist, 59, pp. 77-92, 2004.

[11] Evans, G. W. \& English, K. The environment of poverty: Multiple stressor exposure, psychophysiological stress, and socioemotional adjustment. Child Development, 73, pp. 1238-1248, 2002. 